\title{
Comparing energy payback and simple payback period for solar photovoltaic systems
}

\author{
Will Kessler ${ }^{1, *}$ \\ ${ }^{1} \mathrm{~N}$ Am Board of Cert Energy Practitioners, REDA LLC, 533 Congress St, Portland, ME 04101 USA
}

\begin{abstract}
Installing a solar photovoltaic (PV) array is both an environmental and a financial decision. The financial arguments often take priority over the environmental because installing solar is capital-intensive. The Simple Payback period (SPB) is often assessed prior to the adoption of solar PV at a residence or a business. Although it better describes the value of solar PV electricity in terms of sustainability, the Energy Payback period (EPB) is seldom used to gauge the merits of an installation. Using published estimates of embodied energies, EPB was calculated for four solar PV plants utilizing crystalline-Si technology: three being actual commercial installations located in the northeastern U.S., and a fourth installation based on a simulated 20-kilowatt roof-mounted system, in Wrocław, Poland. Simple Payback was calculated based on initial capital cost, and on the availability of avoided electricity costs based on netmetering tariffs, which at present in the U.S. are 1:1 credit ratio, and in Poland is 1:0.7 credit ratio. For all projects, the EPB time was estimated at between 1.9 and 2.6 years. In contrast, the SPB for installed systems in the northeastern U.S. ranged from 13.3 to 14.6 years, and was estimated at 13.5 years for the example system in Lower Silesia, Poland. The comparison between SPB and EPB shows a disparity between motivational time frames, in which the wait for financial return is considerably longer than the wait for net energy harvest and the start of sustainable power production.
\end{abstract}

\section{Introduction}

The adoption of solar photovoltaic (PV) generation at a given site is a blend of feasibility and motivations - both economic and environmental. The technical aspects can include: roof orientation and pitch, solar access, roof composition, land usage, geology, soil character, proximity to the power grid, and many others. On the other hand, financial variables include questions of access to working capital, cost of installation, and the cost of avoided electricity. The Simple Payback Period (SPB) is a commonly cited measure of the

\footnotetext{
${ }^{*}$ Corresponding author: tankfullofsun@gmail.com
} 
time in years, between initial outlay of capital on a solar installation and the return on initial investment. The Simple Payback period of a solar PV installation may be expressed:

$$
S P B=\left(c_{\text {system }}\right)\left(Q_{\text {year }^{-l}}\right)\left(P R^{-l}\right)\left(P^{-l}\right)\left(c_{\text {elec }^{-l}}\right)
$$

where $c_{\text {system }}$ is the un-subsidized installed system cost, $Q_{\text {year }}$ is the total annual irradiation for an optimally-inclined array at the location [1], $P R$ is the system's annual DC to AC performance ratio [2], $P$ is the system DC capacity in Watts, and $c_{\text {elec }}$ is the cost of electricity that is avoided by the system's local production. The usefulness of the SPB calculation is that it is an intuitive expression of expenses and returns. However it carries a high degree of variability due the fluctuation of $c_{\text {elec }}$, i.e. the market electricity rate. Historically, SPB for solar PV installations has decreased, as the cost of producing PV modules and $c_{\text {system }}$ has decreased [3, author's industry observation].

The merits of a solar PV installation as an energy investment are described with an analogous term, called Energy Payback (EPB), which may be expressed:

$$
E P B=\left(E_{\mathrm{M}}+E_{\mathrm{INV}}+E_{\mathrm{BOS}}\right)\left(Q_{\mathrm{year}^{-1}}\right)\left(P R^{-I}\right)\left(P^{-l}\right)
$$

where $E_{\mathrm{M}}, E_{\mathrm{INV}}$, and $E_{\mathrm{BOS}}$ represent the embodied energy of the solar modules, the DC-to-AC inverters, and Balance of System (BOS), respectively [4]. Where SPB estimates the wait time for the recoup of initial capital outlay, the EPB expresses the time required for the PV array to generate an amount of energy equivalent to its initial energy inputs, and start net energy production.

This work presents estimated EPB and SPB calculations, for three completed solar photovoltaic installations, and one typical installation based on published estimates of embodied energy and current industry and market parameters. In assessing the differences between EPB and SPB, the question arises of how best to motivate and accelerate adoption of sustainable, local PV harvest, given its comparatively short Energy Payback period.

\section{Methods}

Simple and Energy Payback periods were calculated for three installed systems in the northeastern U.S. including a ground-mounted array located in Thornton, NH (lat. 43.936740, long. - 71.683367), a pitched-roof array located in Franconia, NH (lat. 44.234389, long. - 71.756667), and a flat-roof array located in Concord, NH (lat. 43.218414, long. - 71.536698). For geographical comparison, payback periods were simulated for a model $20 \mathrm{~kW}$ DC array located in Lower Silesia Poland (lat. 51.108752, long. - 17.059876).

All SPB estimates assumed electricity escalation rates of 3\% [5], a $0 \%$ discount rate, zero cash incentives, and used the electricity tariffs applicable for each customer at the time of system installation, as shown in Table 1. Mean solar production for U.S. locations was modelled using the American National Renewable Energy Laboratory's typical meteorological year data sets (TMY2, TMY3) [6]. Mean solar production for the Polish site was modelled from the Photovoltaic Solar Electricity Potential in European Countries data set [1]. The simulated SPB for the Lower Silesian PV system also assumed solar production was consumed behind the meter $50 \%$ of the time for $1: 1$ cost offset, and exported $50 \%$ of the time for 1:0.7 cost offset based on the recently enacted Odnawialne Źródła Energii (Renewable Energy Sources) laws. An installed cost of 7PLN per WDC was used [author's industry observation].

Energy payback period was calculated using primary energy in all instances, assuming a grid efficiency factor of 0.35 , and balance of materials records from the three existing projects in the northeastern U.S. Specifically, Balance of System $\left(E_{\mathrm{BOS}}\right)$ was calculated as 
the sum of embodied energies by mass of Aluminum, Steel, Copper, PVC, and Concrete materials used in the solar PV system, based on estimates by Frankl et al. [7]. For all four systems, embodied energy of poly-Si and mono-Si photovoltaic modules $\left(E_{\mathrm{M}}\right)$ followed from Peng et al. [4], and embodied energy of the PV inverter by AC wattage $\left(E_{\mathrm{INV}}\right)$ followed from estimates published by Alsema [8]. Energy payback for the simulated 20 kilowatt system referenced the same estimates of $E_{\mathrm{M}}$ [4] and $E_{\mathrm{INV}}$ [8]. However $E_{\mathrm{BOS}}$ estimates were based on a linear extrapolation from the roof-attached Franconia array, using an empirically determined $E_{\mathrm{BOS}}$ coefficient of $95.7 \mathrm{kWh} / \mathrm{m}^{2}$ of array.

\section{Results}

The estimated SPB and EPB for installed and modelled PV systems are presented in Tables 1 and 2 , respectively.

Table 1. Estimated Simple Payback periods for three actual and one simulated solar PV system.

\begin{tabular}{|c|c|c|c|c|c|}
\hline Generator & Commissioned & $\begin{array}{c}\text { System size } \\
\text { kW DC }\end{array}$ & $\begin{array}{c}\text { Solar } \\
\text { production }\end{array}$ & $\begin{array}{c}\text { Elec. Tariff } \\
\mathbf{\$} / \mathbf{k W h}\end{array}$ & $\begin{array}{c}\text { Simple } \\
\text { Payback }\end{array}$ \\
\hline $\begin{array}{c}\text { Hubbard Brook } \\
\text { Research Foundation } \\
\text { Thornton, NH USA }\end{array}$ & 2015 & 40.56 & $\begin{array}{c}44,800 \\
{[6]}\end{array}$ & $\$ 0.177$ & 13.3 \\
\hline $\begin{array}{c}\text { Gale River Motel } \\
\text { Franconia, NH USA }\end{array}$ & 2016 & 13.78 & $\begin{array}{c}15,540 \\
{[6]}\end{array}$ & $\$ 0.170$ & 13.8 \\
\hline $\begin{array}{c}\text { Grappone Conf. } \\
\text { Center }\end{array}$ & 2016 & 143.6 & $\begin{array}{c}160,000 \\
{[6]}\end{array}$ & $\$ 0.126$ & 14.6 \\
Concord, NH USA & -- & 20.0 & $\begin{array}{c}19,000 \\
{[1]}\end{array}$ & $\begin{array}{c}\text { *[based on } \\
3.96 \text { PLN } \\
\text { 1 USD] }\end{array}$ & 13.5 \\
\hline $\begin{array}{c}\text { Sample roof mounted } \\
\text { Mono-Si PV array } \\
\text { Optimal orientation } \\
\text { Wrocław, Poland }\end{array}$ & & & & \\
\hline
\end{tabular}

Table 2. Estimated Energy Payback along with estimate sources for three actual and one simulated solar PV system.

\begin{tabular}{|c|c|c|c|c|c|c|}
\hline \multirow{2}{*}{ Generator } & \multirow{2}{*}{$\begin{array}{c}\text { Primary energy } \\
\text { prod. (kWh) }\end{array}$} & \multicolumn{2}{|c|}{ Estimated primary energy inputs } & Total & $\begin{array}{c}\text { Energy } \\
\text { Payback } \\
\text { vears }\end{array}$ \\
\cline { 3 - 5 } & PV module & BOS & Inverter & & 2.4 \\
\hline $\begin{array}{c}\text { Hubbard Brook } \\
\text { Research } \\
\text { Foundation }\end{array}$ & 128,000 & $\begin{array}{c}213,600 \\
{[4,10]}\end{array}$ & $\begin{array}{c}80,000 \\
{[7]}\end{array}$ & $\begin{array}{c}13,200 \\
{[8]}\end{array}$ & 306,800 & 2.4 \\
\hline $\begin{array}{c}\text { Gale River Motel } \\
\text { Franconia, NH } \\
\text { USA }\end{array}$ & 44,400 & $\begin{array}{c}71,200 \\
{[4,10]}\end{array}$ & $\begin{array}{c}8,000 \\
{[7]}\end{array}$ & $\begin{array}{c}4,300 \\
{[8]}\end{array}$ & 83,500 & 1.9 \\
\hline $\begin{array}{c}\text { Grappone Conf. } \\
\text { Center }\end{array}$ & 457,100 & $\begin{array}{c}888,800 \\
{[4,10]}\end{array}$ & $\begin{array}{c}40,400 \\
{[7]}\end{array}$ & $\begin{array}{c}38,500 \\
{[8]}\end{array}$ & 967,700 & 2.1 \\
Concord, NH USA & & & & & & \\
\hline $\begin{array}{c}\text { Sample roof } \\
\text { mounted }\end{array}$ & & 123,600 & 11,000 & 7,800 & 142,400 & 2.6 \\
$\begin{array}{c}\text { Mono-Si PV array } \\
\text { Optimal orientation }\end{array}$ & 54,300 & $4,10]$ & & & & \\
Wrocław, Poland & & & & & & \\
\hline
\end{tabular}


Table 3. Balance of System summary for driven-post, ground-mounted solar system in Thornton, NH USA.

\begin{tabular}{|c|c|c|c|c|c|c|c|c|c|}
\hline Material & Aluminum & & Steel & & PVC & & Copper & & Total \\
\hline $\mathbf{k g}$ & 1,418 & $\begin{array}{c}\text { Racking } \\
\text { system }\end{array}$ & 1,256 & Posts & 85 & Conduit & 37 & Conductors & \\
\hline & 69 & Fasteners & 73 & $\begin{array}{c}\text { Channel } \\
\text { strut }\end{array}$ & 9 & Misc. & & & \\
\hline & 162 & Conductors & 92 & $\begin{array}{c}\text { Misc. } \\
\text { electrical }\end{array}$ & & & & & \\
\hline subtotal & 1,649 & & 1,428 & & 94 & & 37 & & \\
\hline $\begin{array}{c}\mathbf{k W h} \\
\text { embodied } \\
{[7]}\end{array}$ & 64,900 & & 12,700 & & 1,700 & & 700 & & 80,000 \\
\hline
\end{tabular}

Table 4. Balance of System summary for pitched-roof solar system in Franconia, NH USA.

\begin{tabular}{|c|c|c|c|c|c|c|c|c|c|}
\hline Material & Aluminum & & Steel & & PVC & & Copper & & Total \\
\hline $\mathbf{k g}$ & 183 & $\begin{array}{c}\text { Racking } \\
\text { system }\end{array}$ & 12 & Fasteners & 1 & Conduit & 8 & Conductors & \\
\hline & 12 & Fasteners & 8 & $\begin{array}{c}\text { Misc. } \\
\text { electrical }\end{array}$ & & & & & \\
\hline & & & 4 & Conduit & & & & & \\
\hline subtotal & 195 & & 24 & & 1 & & 8 & & \\
\hline $\begin{array}{c}\mathbf{k W h} \\
\text { embodied [7] }\end{array}$ & 7,660 & & 213 & & 19 & & 152 & & 8,000 \\
\hline
\end{tabular}

Table 5. Balance of System summary for ballasted, flat-roof solar system in Concord, NH USA.

\begin{tabular}{|c|c|c|c|c|c|c|c|c|c|c|c|}
\hline Material & $\begin{array}{c}\text { Aluminu } \\
\mathrm{m}\end{array}$ & & Steel & & $\begin{array}{c}\text { Concret } \\
\mathrm{e}\end{array}$ & & PVC & & Copper & & Total \\
\hline \multirow[t]{5}{*}{ kg } & 31 & $\begin{array}{c}\begin{array}{c}\text { Racking } \\
\text { system }\end{array} \\
\end{array}$ & 2,524 & \begin{tabular}{|c|} 
Racking \\
system \\
\end{tabular} & 9,973 & \begin{tabular}{|c|} 
Ballast \\
$\mathrm{s}$ \\
\end{tabular} & 22 & $\begin{array}{c}\text { Condu } \\
\text { it }\end{array}$ & 149 & $\begin{array}{c}\text { Conduct } \\
\text { ors }\end{array}$ & \\
\hline & 59 & $\begin{array}{c}\text { Conductor } \\
\mathrm{s}\end{array}$ & 26 & Fasteners & & & & & & & \\
\hline & 7 & Fasteners & 266 & $\begin{array}{c}\text { Channel } \\
\text { strut }\end{array}$ & & & & & & & \\
\hline & & & 286 & $\begin{array}{c}\begin{array}{c}\text { Conduit } \\
\text { and } \\
\text { wireway } \\
\mathrm{s}\end{array} \\
\end{array}$ & & & & & & & \\
\hline & & & 123 & \begin{tabular}{|c|} 
Misc. \\
electrical
\end{tabular} & & & & & & & \\
\hline subtotal & 98 & & 3,225 & & 9,973 & & 22 & & 149 & & \\
\hline $\begin{array}{c}\text { kWh } \\
\text { embodied } \\
{[7]}\end{array}$ & 3,840 & & $\begin{array}{c}28,70 \\
0\end{array}$ & & 4,520 & & 408 & & 2,900 & & $\begin{array}{c}40,40 \\
0\end{array}$ \\
\hline
\end{tabular}

Detailed balance of materials lists are shown in Tables 3, 4, and 5. For the systems in operation in the northeastern U.S., simple payback ranged from 13.3 years to 14.6 years. For the simulated system in southwest Poland, simple payback was estimated at 13.5 years. The estimated EPB for existing installations ranged from 1.9 years for a pitched-roof attached-railing system in Franconia, to 2.4 years for a pile-driven ground mount array in Thornton. The existing ballasted flat-roof system in Concord showed an EPB of 2.1 years. The simulated roof mounted PV array in Lower Silesia (Wrocław) had an EPB of 2.6 years. 


\section{Discussion}

Between the years 1977 and 2013, the average cost of crystalline-Si photovoltaic cells dropped from 76.67 USD/W, to 0.74 USD/W [3], and this trend continues in 2017, as average PV cell prices drop below 0.30 USD/W [author's industry observation]. Nonetheless the capital investment required to purchase and install a distributed solar PV generator is great enough that out-of-pocket costs and simple payback scenarios guide customers' decision-making. Comparisons of EPB and SPB show significantly shorter wait times for the harvest and return of $100 \%$ of the energy invested in the solar equipment and the start of net energy harvest, compared to the wait for financial returns.

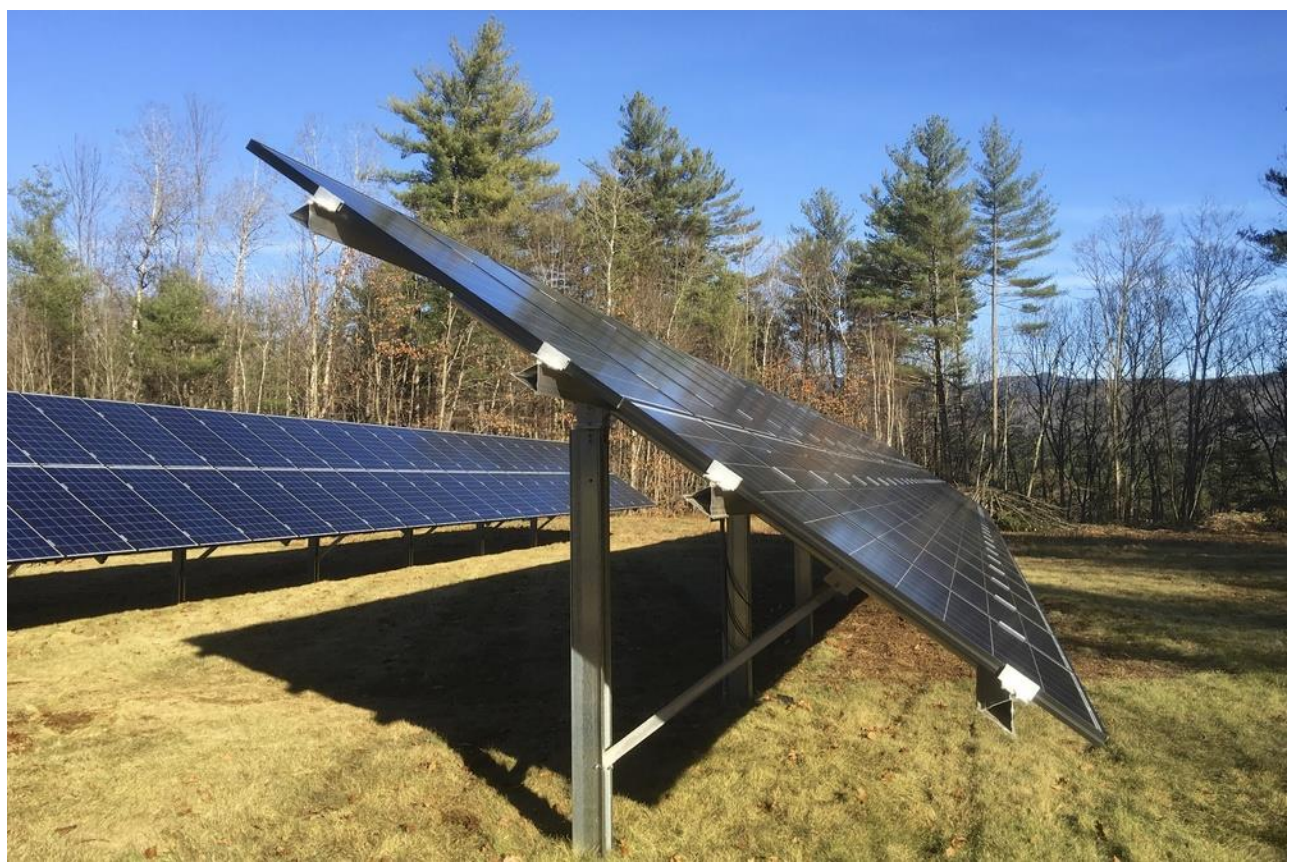

Fig. 1. Ground-mounted solar photovoltaic arrays at the Hubbard Brook Reseaerch Foundation. The system's estimated energy payback period of 2.4 years was significantly less than the simple payback period, 13.3 years. Note the driven-post system reaches soil depth of $2.4 \mathrm{~m}$, and requires no concrete to install.

Energy payback improves alongside advancements in module manufacturing, solar installation techniques, and cell efficiencies. For example, the EPB times calculated in the present study for the northeastern U.S. and Poland are significantly shorter than the EPBs surveyed for systems of similar or greater productivity that were installed between 2003 and 2006 [9]. Furthermore, the $E_{\mathrm{BOS}}$ estimated for the ground-mounted array at Hubbard Brook, pictured in Figure 1, was $319 \mathrm{kWh} / \mathrm{m}^{2}$, small in comparison to previously published estimates of ground mounting balance of system embodied energies [10,11]. However, it is unlikely that continuing technological advancement will decrease the EPB below certain physical thresholds due to constraints such as resource scarcity, transportation and mobilization costs, and labor costs of installation.

Incentivizing renewable energies by shortened SPB, or low cost loan presents a valid goal based on the physical merits of low-EPB solar generation. In mature solar markets, two policies have been successfully adopted and replicated, and may be worth long term implementation: a) Production-based incentives such as a mandated offer or a feed in tariff 
guarantee, and b) Low-cost financing programs, which allow the expense of equipment and installation to be spread out over the lifetime of the solar equipment.

The author would like to thank Marta A. Kessler for her patience and swiftness, without which little if any of the solar field work or post-project investigations would be possible.

\section{References}

1. M. Šúri, T.A. Huld, E.D. Dunlop, H.A. Ossenbrink, Sol. Energy 81, 1295-1305 (2007)

2. B. Marion, J. Adelstein, K. Boyle, H. Hayden, B. Hammond, T. Fletcher, B. Canada, D. Narang, D. Shugar, H. Wenger, A. Kimber, L. Mitchell, G. Rich, T. Townsend, IEEE Phot Spec Conf CP-520-37358 (2005)

3. Bloomberg Finance L.P., Sustainable Energy in America, 2015 Factbook, http://www.bcse.org/wp-content/uploads/2015-Sustainable-Energy-in-AmericaFactbook.pdf (accessed 28 March 2017)

4. J. Peng, L. Lu, H. Yang, Renew. Sust. Energ. Rev. 19, 255-274 (2013)

5. Energy Information Administration, Electric Power Annual - State Data Tables, https://www.eia.gov/electricity/annual/ (accessed 28 March 2017)

6. A. P. Dobos, PVWatts version 5 manual (2014)

7. P. Frank1, A. Masini, M. Gamberale, D. Toccaceli, Prog. Photovoltaics 6, 137-146 (1998)

8. E. Alsema, Energy pay-back time and $\mathrm{CO}_{2}$ emissions of photovoltaic systems, in Markvart and Castañer (Eds.), Practical Handbook of Photovoltaics: Fundamentals and Application, 1097-1117 (Elsevier, Kidlington, UK, 2003)

9. W. Kessler, S. Dornblut, Solar Today 11/12, 32-35 (2009)

10. N. Jungbluth, M. Stucki, R. Frischknecht, S. Büsser, Photovoltaics, in Dones et al. (Eds.), Sachbilanzen von Energiesystemen: Grundlagen für den ökologischen Vergleich von Energiesystemen und den Einbezug von Energiesystemen in Ökobilanzen für die Schweiz, Ecoinvent Report 6 - XII (ESU-services Ltd, Uster, CH, 2010)

11. J.M. Mason, V.M. Fthenakis, T. Hensen, H.C. Kim, Progress in Photovoltaic Research and Applications 14, 179-90 (2006) 